the advantages of Section 1404(a). In view of the broad language of Section 1404(a), and the cases which have held that 1404(a) does apply to removal cases as well as those instituted in a federal court, ${ }^{44}$ it may easily be decided that transfer would continue to apply to removal cases even though changes were made in the federal doctrine of jurisdiction over foreign corporations. ${ }^{45}$

The other problems in adopting such a suggestion do not appear to be insurmountable. The major difficulty lies in certain conventional ideas about "jurisdiction over parties," but these ideas have been under attack in recent years. The advantages in fairness and speedy administration of justice to be gained by the liberal application of Section 1404(a) should more than offset the difficulties involved in eliminating the second requirement of International Shoe and considering questions of inconvenience solely under the motion for transfer.

removal case on the doctrine of Erie Railroad Co. v. Tompkins, 304 U.S. 64 (1938), consult Braucher, The Inconvenient Federal Forum, 60 Harv. L. Rev. 908 (1947).

${ }^{44}$ Chicago, R. I. \& P. R. Co. v. Igoe, 212 F. 2 d 378 (C.A. 7th, 1954); Grivas v. Parmelee Transp. Co., 207 F. 2d 334 (C.A. 7 th, 1953); Stewart v. Atchison, T. \& S.F. Ry. Co., 92 F. Supp. 172 (E.D. Mo., 1949). These cases, of course, arise when the jurisdictional requirements in the state and federal courts are identical.

${ }^{45}$ Consult Freeman v. Bee Machine Co., 319 U.S. 448 (1943), which overcame a technical barrier when it allowed an amendment to the complaint under a federal law although the amendment could not have been made in the state court.

\title{
MEDICAI SOCIETIES AND MEDICAL SERVICE PLANS-FROM THE LAW OF ASSOCIATIONS TO THE LAW OF ANTITRUST
}

The American Medical Association and its affiliated organizations are the avowed advocates of solo, fee-for-service medical practice. The ethics promulgated during a long fight for better standards in the profession, especially when coupled with traditional concepts of professionalism, admit of little variation. In comparison to the accepted methods of practice, ${ }^{1}$ prepayment group-practice plans are almost heretic. Often organized by unions, industrial management, or other lay sponsors, they combine the insurance principle of prepayment with the benefits obtainable through groups of general practitioners and specialists working on other than a fee-for-service basis with fully equipped clinics at their disposal. $^{2}$

1 In an exhaustive comment on the AMA, the Yale Law Journal has analyzed organized medicine's methods of opposition to disapproved practices. There it is indicated that the power of the medical societies is such that coercion directed against physicians affiliated with disapproved plans can be an effective weapon. The American Medical Association: Power, Purpose, and Politics in Organized Medicine, 63 Yale L. J. 937 (1954).

${ }^{2}$ See generally, Hunt \& Goldstein, Medical Group Practice in the United States (U.S. Public Health Service Publication No. 77, 1951); Serbein, Paying for Medical Care in the United States (1950); George Baehr, M.D. (President and Medical Director of the Health Insur-

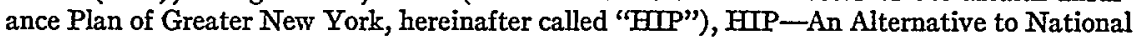


The Health Insurance Plan of Greater New York (HIP), for example, has thirty contractually affiliated groups of physicians offering comprehensive medical care to its subscribers for a set premium. The subscribers enroll in one of the medical groups, which is compensated on a per capita basis for each enrollee irrespective of the frequency or the nature of the services rendered. The medical groups, after paying the operating expenses of their clinics, divide this income as they wish; most physicians engaged in the plan choose salaried practice. ${ }^{3}$

Recently, the Medical Society of the State of New York upheld a component county society's censure of a physician affliated with HIP, and adopted clarifications to its Principles of Medical Ethics. ${ }^{4}$ The censure action was based on the premise that solicitation by HIP was in effect advertising for the benefit of the affiliated physicians and thus violated the society's ethic against advertising. ${ }^{5}$ The censure was coupled with a warning to members of the county society that "like conduct ... will be deemed sufficient basis for disciplinary action, and will be dealt with accordingly." 6 The clarifications codify the county society's interpretation of the advertising ethic; in addition they declare contract practice unethical unless the patients are public charges, and the free-choice-ofphysician ethic is deemed violated where subscribers are restricted to a limited panel of physicians under contract. ${ }^{7}$

The Judicial Council of the AMA has reversed the censure action, holding that HIP's advertising was not for the benefit of Dr. Landess and that "the conduct of Dr. Landess [did] not violate the ethic relating to soliciting and

Compulsory Medical Insurance, 17 Conn. St. Med. J. 29 (1953); Means, Doctors, People and Government (1953).

${ }^{3} \mathrm{HICP}$ does not provide hospitalization, but subscribers are required to carry Blue Cross or commercial insurance coverage for hospitalization costs. Enrollment in HIP is open only to groups of employees with a common employer, with some exceptions. To enable lower-paid workers to subscribe, the employer must pay half the premium. In some instances the entire premium is paid by the employer or by a union welfare or trust fund. Baehr, op. cit. supra note 2, at 32; testimony of George Baehr, M.D., Hearings before House Committee on Interstate and Foreign Commerce on Voluntary Health Insurance, 83d Cong. 2d Sess. 1585 (1954). The City of New York pays half of the premium for municipal employees enrolled in HIP, N.Y. Gen'l Municipal Law $\$ 93$ (McKinney, 1954), but not for employees enrolled in indemnity or other non-comprehensive plans. See Master, The Impact of Medical Care Plans on the Medical Profession, 150 J. Am. Med. Ass'n 766 (1952).

${ }^{4}$ N.Y. Times, p. 1, cols. 3-4, p. 32, cols. 4-6 (May 13, 1954).

5 Principles of Medical Ethics of the American Medical Ass'n, c. 1, $\$ 4$; Principles of Professional Conduct of the Medical Society of the State of New York, c. 1, $\$ 4$; Principles of Professional Conduct-As Agreed to by the Five County Medical Societies in Greater New York, § 23. Consult N.Y. Education Law § 6514 (McKinney, 1953) (advertising or soliciting a ground for revocation of license to practice medicine).

' Report of the Board of Censors of the Medical Society of the County of Queens, adopted by the Queens County Society on September 30,1952, reprinted in the Memorandum for the Appellant before the House of Delegates, Medical Society of the State of New York, Matter of Ben E. Landess, M.D., at 29-30 (hereinafter cited as Memorandum for Dr. Landess).

${ }^{7}$ N.Y. Times, loc. cit. supra note 5 . 
advertising." But the clarifications were not in issue in the Landess appeal, and the free-choice question, although commented upon, was not dealt with by the Judicial Council on the ground that this issue was not directly involved in the censure of Landess. Thus, the threat to prepayment group-practice plans implicit in these clarifications remains. ${ }^{9}$

The characterization of a practice as unethical forbodes the possible use of formal sanctions, such as censure, suspension, expulsion, or-equally as important-denial of admission. ${ }^{10}$ Membership in the AMA is often the criterion of professional competency. As a non-member, the physician will find it difficult to obtain malpractice insurance, will be ineligible for specialty board ratings, and referrals and consultations may be denied him.11 Expulsion or denial of membership carries the added "stigma of unethical practice."12 A physician in that position may be unable to secure assistance in emergencies, may be unable to obtain the use of hospital facilities, and will be excluded from participation in the medical and scientific programs of medical societies. ${ }^{13}$ "It is the practitioner who is expelled or denied membership who finds the punitive tactics of organized medicine employed to the fullest against him. In these cases, nonmembership amounts to a partial revocation of licensure to practice medicine."14

Despite the economic detriment that results from the use of medical society

${ }^{8}$ Appeal of Dr. Ben E. Landess to the Judicial Council of the American Medical Ass'n, 157 J. Am. Med. Ass'n 753 (1955).

${ }^{9}$ See pp. 714-18 infra.

"The point is that comprehensive medical care cannot be provided on a fee-for-service basis. It has been tried in California and Michigan and has failed because physicians, when remunerated by an insurance company on a fee-for-service basis, tend to multiply services. As a result, the insurance plan is soon bankrupt or it must raise its premium rates or it must reduce the benefits to subscribers. Therefore, insurance companies like the Blue Shield plans limit their benefit coverage, place limitations on the number of services that may be rendered in any one illness, introduce waiting periods, and offer no preventive or diagnostic services. Also, additional doctors' charges are permitted even for service benefits for all subscribers above a very low income level." Letter from Jeannette Fleisher, Administrative Assistant, HIP (May 28, 1954). Consult AMA, Voluntary Prepayment Medical Benefit Plans (1953); Testimony of Nelson B. Cruikshank (Director of Social Insurance Activities, A.F. of L.), Hearings before House Committee on Interstate and Foreign Commerce on Voluntary Health Insurance, 83d Cong. 2d Sess. (1954); Yale L. J., op. cit. supra note 1, at 980-85; Serbein, op. cit. supra note 2.

${ }^{10}$ See generally, Yale L. J., op. cit. supra note 1, at 949-53. General recognition of the need for standards in the medical profession has made the use of formal sanctions rare. "Because the AMA has the consent and support of a great majority of doctors, its standards can often be enforced against an offender without formal action. The physician who is suspected of 'unethical' practice may be subjected to professional ostracism.... The mere availability of such [informal] sanctions is usually enough to deter possible violators of AMA's code of conduct." Ibid., at 949. See also, Group Health Cooperative of Puget Sound v. King County Medical Society, 39 Wash. 2d 586, 623-29, 663-64, 667, 669, 237 P. 2d 737, 757-60, 778-81 (1951).

11 Yale L. J., op. cit. supra note 1, at 951-53; consult note 79 infra.

12 Yale L. J., ibid., at 952.

${ }^{13}$ Consult note 79 infra.

14 Yale L. J., op. cit. supra note 1, at 953. 
power, the courts have been reluctant to interfere. The more obvious instances of society pressure on the individual can be reached through the injunctive decree. ${ }^{15}$ But subtler forms of coercion, such as social and professional ostracism or veiled threats of formal sanctions, are totally beyond the reach of judicial power. Even where the coercion is subject to judicial control, common-law concepts have shackled efforts at relief. The case law does indicate, however, that judicial relief is available where organized medicine's activities result in restraints on organizations like HIP. The development and efficacy of the legal theories which have been used as bases for judicial intervention are the subject matter of this comment.

The attempted emasculation of prepayment group-practice medical care plans is justified in terms of ethics and directed against the participating physicians, rather than against the plans per se. When the issue is thus phrased as an intraorganizational dispute, the aggrieved physician finds himself confronted with the traditional reluctance of the courts to intervene in the internal affairs of voluntary associations..$^{16}$ In addition, the refusal of the courts to attribute the status of a trade to the practice of medicine may place interference with medical practice outside the scope of applicable antitrust laws. ${ }^{17}$ The effects of expulsion are grave, however, and the reluctance of the courts to intervene is taxed when the facts show an invasion of basic individual rights.

Traditionally, two rationales-one a property and the other a contract theory -are used as bases for judicial intervention and relief. The varying effects of the property theory can be illustrated by a comparison of Waring v. Georgia Medical Society ${ }^{18}$ with Hyde v. Jackson County Medical Society. ${ }^{19}$ In the Waring case the court found "a property in the franchise" conferred upon the corporators and their successors by reason of incorporation; this was tantamount to holding that membership itself is a property right worthy of protection. ${ }^{20}$ In the

${ }^{15}$ E.g., Marcus, Civil Rights and the Anti-trust Laws, 18 U. of Chi. L. Rev. 171, 196-97 (1951) (injunction issued by a Florida court to enable a physician affiliated with a cooperative health plan to use hospital facilities).

${ }^{16}$ Consult Chafee, The Internal Affairs of Associations Not for Profit, 43 Harv. L. Rev. 993 (1930); Pound, Equitable Relief against Defamation and Injuries to Personality, 29 Harv. L. Rev. 640 (1916); Ford, The Use of the Injunction To Restrain Wrongful Expulsion from Voluntary Associations, 1 Sydney L. Rev. 186 (1954); Laski, The Personality of Associations, 29 Harv. L. Rev. 404 (1916); Dodd, Dogma and Practice in the Law of Associations, 42 Harv. L. Rev. 977 (1929).

${ }^{17}$ See American Medical Ass'n v. United States, 317 U.S. 519 (1943); cf. United States v. National Ass'n of Real Estate Boards, 339 U.S. 485, 492 (1950).

$1838 \mathrm{Ga} .608$ (1869).

${ }^{19} 295$ Mo. 144, 243 S.W. 341 (1922).

${ }^{20}$ Waring v. Georgia Medical Society, 38 Ga. 608, 626 (1869). See Medical and Surgical Society of Montgomery County v. Weatherly, $75 \mathrm{Ala} .248$ (1883), and Weatherly v. Medical and Surgical Society of Montgomery County, $76 \mathrm{Ala} .567$ (1884), approved in Medical Society of Mobile County v. Walker, 245 Ala. 135, 138-39, 16 So. 2d 321, 324-25 (1944). 
Hyde case this thesis was expressly rejected, and the court refused jurisdiction because of "the better considered rule that the property right which is violated must be a severable proprietary right." 21 The property theory has been criticized because it is open to such narrow construction, ${ }^{22}$ but the weight of authority in medical society discipline cases supports this formulation. ${ }^{23}$

The contract theory posits that the constitution and by-laws of the medical society constitute a contract between the member and the organization. $.^{24} \mathrm{Dis}-$ cipline can be imposed only for offenses defined in the contract, and then only if the provisions are not contrary to law or public policy. Further, the disciplinary procedure must be fair and in accordance with the by-laws. ${ }^{25}$ Any disciplinary action taken by a medical society which does not trespass upon these limitations is said to be conclusive. ${ }^{26}$

Strict adherence to this doctrine would virtually preclude judicial interference, because "[p]unishable offenses are uniformly stated in vague terms which can easily be construed to prohibit any conduct which the officers may desire to punish." ${ }^{27}$ Hence, the limitations, if any, on the application of the contract theory are to be found in the extent to which the courts find the provisions or interpretations contrary to law or public policy.

Another hurdle to relief is the familiar rule of the law of voluntary associations that an appeal to the courts can be had only when all appeals within the association have been exhausted. ${ }^{28}$ The rule, however, is riddled with exceptions, ${ }^{29}$ the most important being that where the disciplinary action is void, relief may be had immediately on the ground that an internal appeal would be useless. Since the situations in which the courts reverse the association's dis-

${ }^{21}$ Hyde v. Jackson County Medical Society, 295 Mo. 144, 158, 243 S.W. 341, 344 (1922). This holding virtually precludes judicial relief for expulsion in Missouri, because of the difficulty of showing the requisite property right. Consult Suspension or Expulsion from Professional Association and the Remedies Therefor, 20 A.L.R. 2d 531 (1951).

22 Consult authorities cited note 16 supra.

${ }^{23}$ E.g., Weyrens v. Scotts Bluff County Medical Society, 133 Neb. 814, 818, 277 N.W. 378, 380 (1938): "A court of equity will not inquire into the regularity or validity of disciplinary proceedings . . . when no civil or property right [of the disciplined member] will be affected.' Rogers v. Tangier Temple, 112 Neb. 166, 198 N.W. 873 [1924]."

${ }^{24}$ E.g., Ewald v. Medical Society of New York County, 144 App. Div. 82, 128 N.Y. Supp. 886 (1911), rev'g 70 Misc. 615, 130 N.Y. Supp. 1024 (S. Ct., 1911).

${ }^{25}$ See, e.g., Medical Society of Mobile County v. Walker, 245 Ala. 135, 138-39, 16 So. 2d $321,324-25$ (1944).

${ }^{26}$ E.g., Smith v. Kern County Medical Ass'n, 19 Cal. 2d 263, 120 P. 2d 874 (1942). Consult authorities cited note 16 supra for discussion of additional limitations, e.g., maliciousness, natural justice.

${ }^{27}$ Summers, Legal Limitations on Union Discipline, 64 Harv. L. Rev. 1049, 1061 (1951); consult also, Summers, The Right To Join a Union, 47 Col. L. Rev. 33 (1947).

${ }^{28}$ E.g., Irwin v. Lorio, 169 La. 1090, 126 So. 669 (1930).

${ }^{29}$ E.g., Brown v. Harris County Medical Society, 194 S.W. 1179 (Tex. Civ. App., 1917). Consult Summers, op. cit. supra note 27, at 1086-91. See Waldman v. Ladisky, 101 N.Y.S. 2d 87, 91 (S. Ct., 1950). But cf. Irwin v. Lorio, 169 La. 1090, 126 So. 669 (1930). 
ciplinary action are those where they consider the action void (e.g., non-punishable offense, non-conformity with law or public policy, unfair trial, and defective procedure as measured by the by-laws of the association) "the obvious effect of the exception is that if a court will give relief at all, it will do so without requiring any internal appeals." 30

The courts have also used a "substantial evidence" rule, but have not applied it consistently. ${ }^{31} \mathrm{It}$ has been used to limit judicial review in various ways, sometimes so as to preclude completely a determination on the merits. ${ }^{32}$ This concept and the property and contract theories have prevented a consideration of whether the application of a restrictive ethic is consistent with the demands of public policy. ${ }^{33}$

The combined effect of this potpourri of doctrines is to make judicial relief in medical society discipline cases extremely difficult. ${ }^{34}$ Intervention has occasionally been based on the rationale either that the procedure was not in con-

${ }^{30}$ Summers, op. cit. supra n. 21, at 1091; see, e.g., Medical Society of Mobile County v. Walker, 245 Ala. 135, 16 So. 2d 321 (1944).

${ }^{31}$ Summers, op. cit. supra note 27, at 1084-86. E.g., compare Brown v. Harris County Medical Society, 194 S.W. 1179 (Tex. Civ. App., 1917), with Irwin v. Lorio, 169 La. 1090, 126 So. 669 (1930). Compare Reid v. Medical Society of Oneida County, 156 N.Y. Supp. 780 (S. Ct., 1915), aff'd without opinion 177 App. Div. 939, 163 N.Y. Supp. 1129 (1917), with Smith v. Kern County Medical Ass'n, 19 Cal. 2d 263, 120 P. 2d 874 (1942). Consult Robson, Justice and Administrative Law, c. IV (3d ed., 1951).

3 Compare Medical Society of Mobile County v. Walker, 245 Ala. 135, 16 So. 2d 321 (1944), with Walker v. Medical Society of Mobile County, 247 Ala. 169, 22 So. 2d 715 (1945). This failure to adjudicate the merits may be due to the relative paucity of medical society discipline cases, which has the effect of making the policy grounds for intervention less urgent, or to the fact that when confronted with a controversy involving a professional organization or professional ethics, a judge cannot help but be aware of his own profession and its sacrosanct ethical heritage.

${ }^{33}$ E.g., Weyrens v. Scotts Bluff County Medical Society, 133 Neb. 814, 277 N.W. 378 (1938). The substantial-evidence rule would seem to have little application in any case, since "the administrative law analogy is inadequate for determining the scope of judicial review of findings of fact. The 'substantial evidence' rule is based in part on confidence in the expertise of the tribunal. Such confidence is misplaced when the tribunal is . . . potentially subject to bias." Summers, op. cit. supra note 27, at 1085-86 (referring to union discipline). Consider also the earlier doctrine that the disciplinary powers of incorporated associations conferred upon them a special and limited judicial power. Gregg v. Massachusetts Medical Society, 11 Mass. 185 (1872).

${ }^{34}$ Hyde v. Jackson County Medical Society, 295 Mo. 144, 243 S.W. 341 (1922) (expulsion proceeding based upon an objectionable letter written by plaintiff failed by one vote in the county society; on appeal, the state society ordered him expelled; relief denied); Miller v. Hennepin County Medical Society, 124 Minn. 314, 316, 144 N.W. 1091, 1092 (1914) (held that there was no reason to enjoin the county society from holding expulsion hearings based upon charges for which plaintiff had been acquitted at a criminal trial "where the result of [the society's] sustaining the charge [would be] no more than a severance of the relations between the association and [the plaintiff]"); Mayfield v. St. Louis Medical Society, 91 Mo. App. 76, 83-85 (1901) (plaintiff admitted that he solicited patients to save his clinic, which he alleged was being driven out of business by other members of the local society who were connected with a competing clinic; relief was denied because solicitation was considered as an infraction of the society's by-laws and "such bodies may adopt what rules they please and they will bind the members"). 
formity to the society's by-laws or was clearly unfair. ${ }^{35}$ An example of this is Broven v. Harris County Medical Society, ${ }^{36}$ where the plaintiff's suit to enjoin the society from expelling him was remanded for trial because of the allegation that he had been first informed of some of the charges on the night the expulsion vote was taken.

Precedent supporting judicial intervention because expulsion was based on improper grounds is not strong. In a Georgia reconstruction-era case where a doctor had been expelled for signing a surety on a bond for a Negro elected to public office and for providing bail for other Negroes, it was held that these acts did not violate a by-law providing for expulsion for ungentlemanly conduct. ${ }^{37}$ In several early New York decisions intervention was based on the theory that the usual rules pertaining to voluntary associations did not apply to medical societies, and it was held that the charter of incorporation of county medical societies allowed expulsion only on the grounds valid at common law for the disenfranchisement of a corporator. ${ }^{38}$ This early line of authority was reversed in Ervald v. Medical Society of New York County, ${ }^{39}$ where it was concluded that the plaintiff was bound by a society by-law providing that a resignation from a member under charges was unacceptable. ${ }^{40}$

${ }^{35}$ Medical and Surgical Society of Montgomery County v. Weatherly, 75 Ala. 248 (1883); Weatherly v. Medical and Surgical Society of Montgomery County, 76 Ala. 567 (1884); Reid v. Medical Society of Oneida County, 156 N.Y. Supp. 780 (S. Ct., 1915), aff'd without opinion 177 App. Div. 939, 163 N.Y. Supp. 1129 (1917); Barrows v. Massachusetts Medical Society, 12 Cush. (Mass.) 402 (1853) (semble).

${ }^{36} 194$ S.W. 1179 (Tex. Civ. App., 1917).

${ }^{37}$ Waring v. Georgia Medical Society, $38 \mathrm{Ga} .608$ (1869).

${ }^{38}$ The original charter of incorporation was N.Y.L. (1806) c. 138. Violation of a duty to the society as a member of the corporation or offenses as a citizen against the laws of the country constituted the only bases for disenfranchisement. The rule was first laid down in Fawcett v. Charles, 13 Wend. (N.Y.) *473 (1835), reiterated in Gray v. Medical Society of the County of Erie, 24 Barb. (N.Y.) 570 (1857), and Bartlett v. Medical Society of Erie County, 32 N.Y. *187 (1865) (held that the right of immediate expulsion must be clear and unquestioned to justify denial of admission), and reaffirmed and then overruled in Ewald v. Medical Society of County of New York, 70 Misc. 615, 130 N.Y. Supp. 1024 (S. Ct., 1911), rev'd 144 App. Div. 82, 128 N.Y. Supp. 886 (1911).

${ }^{39} 144$ App. Div. 82, 128 N.Y. Supp. 886 (1911), rev'g 70 Misc. 615, 130 N.Y. Supp. 1024 (S. Ct., 1911).

${ }^{40} \mathrm{Ibid}$. The plaintiff's suspension had been revoked so that he could be expelled for falsifying hospital records. His resignation was held ineffective by the society, but the New York Supreme Court enjoined the society from holding hearings on his expulsion. The court based its decision on three points: (1) that the permissible grounds for expulsion from medical societies, subsequently particularized by statute, had been correctly delineated in the earlier cases; (2) that to refuse a member's resignation in order that he might be expelled was an attempt to regulate the practice of medicine, a function vested in the state and beyond the powers of a private association; (3) that the plaintiff was not bound by the by-law preventing resignation when under charges by virtue of his membership in the society since the bylaw was ultra vires.

The Appellate Division, on the other hand, refused to interfere with the medical society's investigatory or punitive powers despite the fact that like powers were vested in the Board of Regents. This orthodox interpretation of the law of voluntary associations was followed sub- 
The physician denied membership in a medical society has no legal grounds available under the law of voluntary associations on which to base an appeal to the courts, ${ }^{41}$ nor does he have a right to appeal within the AMA. ${ }^{42}$ This makes denial of membership a particularly effective weapon against doctors just entering the profession and those who contemplate moving to a new locale. The right of a medical society to deny admission has been upheld in two cases, ${ }^{43}$ one of which resulted in the court's ordering admission. ${ }^{44}$ This apparent anomaly arose on a petition by a member of a county society to enjoin the society from enrolling two physicians whose applications had received a sufficient number of adverse votes to bar membership. ${ }^{45}$ The applicants had been blackballed pursuant to an agreement between plaintiff and others to thwart all admissions for the duration of the war, but the state society had directed that the applicants be enrolled. The court ignored the obvious attempt to restrain competition in the practice of medicine, choosing rather to rely on the contractual and statutory relationship between the state and county societies to uphold dismissal of the suit.

sequently in New York in Reid v. Medical Society of Oneida County, 156 N.Y. Supp. 780 (S. Ct., 1915), aff'd without opinion 177 App. Div. 939, 163 N.Y. Supp. 1129 (1917).

To complete the picture of the tactics available to organized medicine in New York, "unprofessional conduct" was added by N.Y.L. (1953) c. 682 , to $\$ 6514$ of the N.Y. Education Law (McKinney, 1953), as a ground for revocation of license. Organized medicine has four representatives on the ten-man Board of Regents' medical grievance committee, with three additional members representing the homeopaths and osteopaths and three representatives of the board itself. This committee is empowered to investigate and hear charges against doctors, although its findings are advisory only and discipline must be imposed by the Board itself after further hearings. N.Y. Education Law (McKinney, 1953) §6515. A physician disciplined may appeal to the courts pursuant to N.Y. Civil Practice Act (Cahill-Parsons, 1946) Art. 78, but the scope of review is narrow. See Bell v. Board of Regents, 295 N.Y. 101, 65 N.E. 2d 184 (1946); Barsky v. Board of Regents, 305 N.Y. 89, 111 N.E. 2d 222 (1953), aff'd 347 U.S. 442 (1954).

${ }^{41}$ Hartigan v. Monongalia County Medical Society, 97 W. Va. 273, 124 S.E. 826 (1924). Cf. Walker v. Medical Society of Mobile County, 247 Ala. 169, 22 So. $2 d 715$ (1945). However, the N.Y. Civil Practice Act (Cahill-Parsons, 1946) Art. 78 provides for a limited court review from the final determination of "any person or aggregate of persons."

42 Yale L. J., op. cit. supra note 1, at 950-51. In New York, appeal to the state society from either discipline or denial of admission is provided by law. N.Y. Membership Corporations Law (McKinney, 1941) §174.

${ }^{43}$ Cases cited note 41 supra.

${ }^{44}$ Walker v. Medical Society of Mobile County, 247 Ala. 169, 22 So. 2d 715 (1945).

${ }^{45}$ The society's demurrer to the bill was held good in Medical Society of Mobile County v. Walker, 245 Ala. 135, 16 So. 2d 321 (1944), because the doctors seeking membership had not been joined. A majority of the court, however, "[could] see no reason for withholding injunctive relief against the anticipated violation of the [society's] constitution.... [T] he constitution of the society is a contract between its members and one that the society itself must observe until changed in legal form." Tbid., at 139-40, 325. The Chief Justice concurred specially on the ground that "the bill ... is properly to be interpreted as disclosing that the two physicians here involved are reputable and in every way worthy of membership ... and in no wise objectionable, either to the association or to this complainant. . . [Clomplainant is seeking the enforcement of a mere abstract right." Ibid., at 141, 326-27. 
Other decisions, also ignoring the restraint issue, have reflected the same refusal to intervene even where expulsion was being used as a regulatory device over the methods or costs of medical care..$^{46}$ In Smith v. Kern County Medical Society, ${ }^{47}$ the expulsion of a member who refused to resign from the staff of a county hospital was based on the ethic that it was "unprofessional for a physician to dispose of his services under conditions which ... interfere with reasonable competition among the physicians of the community."48 The society's objections to the hospital were that it was admitting patients who could afford private medical care, and that the resulting overcrowding had made the standard of medical care inadequate. In 1933, members of the society, as individuals, had petitioned for an injunction to correct these alleged abuses; they had asked, among other things, that the hospital's admissions be limited to indigents. Injunctive relief was granted, but the decree was later modified on appeal because the court considered it too harsh insofar as it would have operated against wage earners who could not both support their families and pay the costs of private hospitalization..$^{49}$

Meanwhile, in 1934 the society had adopted a new constitution and set of by-laws, embodying the "reasonable competition" ethic, pursuant to which the petitioner was expelled in 1935 . The society contended in support of its action that

the petitioner had ... participated in a political policy to monopolize the care ... of the sick by the county of Kern at public expense ... with the object and purpose of interfering with reasonable competition among physicians in the community; [as a result of which] the ... hospital became overcrowded ... so that it was impossible to render adequate service. ${ }^{50}$

${ }^{46}$ In Weyrens v. Scotts Bluff County Medical Society, 133 Neb. 814, 277 N.W. 378 (1938), the plaintiff was expelled for treating indigents at a fifty per cent reduction in fees, despite a formal change in medical society policy in 1935 calling for abandonment of this practice. He showed that as a result of expulsion he was dropped from the staff of the only local hospital equipped for the surgical practice for which he was experienced. Relief was denied because of non-exhaustion of remedies and because "no civil or property right of the plaintiff has been invaded by the disciplinary action of the defendant society." The "plaintiff knew [the hospital's] rule and took the consequences when he ... violated the rule set up by the county society." Ibid., at 817-18, 379-80. See Gregg v. Massachusetts Medical Society, 111 Mass. 185 (1872) (physicians were expelled pursuant to a newly adopted by-law declaring the practice of homeopathy unethical).

4719 Cal. 2d 263, 120 P. 2d 874 (1942).

48 Ibid., at 267, 876-77: "It is unprofessional for a physician to dispose of his services under conditions that make it impossible to render adequate services to his patients or which interfere with reasonable competition among the physicians of the community. To do this is detrimental to the public and to the individual physician, and lowers the dignity of the profession." Note that the economic thrust of the ethic is softened by a general warning concerning adequate service and a reference to professionalism. Medical societies nearly always phrase their disciplinary measures in moral rather than economic terms, although the case law indicates that this is unnecessary. For another example of the use of the "reasonable competition" ethic, see Irwin v. Lorio, 169 La. 1090, 126 So. 669 (1930), and text at notes 54-57 infra.

${ }^{49}$ Goodall v. Brite, 11 Cal. App. 2d 540, 54 P. 2d 510 (1936).

50 Smith v. Kern County Medical Ass'n, 19 Cal. 2d 263, 267, 120 P. 2d 874, 877 (1942). "It was also charged that the petitioner [helped to create] a political issue in the campaign 
In his suit for reinstatement the expelled physician contended that if the objectionable conditions did exist, the society's remedy was by way of contempt proceedings for a violation of the injunctive order, not expulsion. The court held that whether or not an alternative remedy was available, the society was not deprived of the right to expel for violations of its resolutions and ethics. ${ }^{51}$

Thus the contract theory is inadequate because it is construed too broadly, and the property theory because it is construed too narrowly. But where the voluntary-association rationale is not applied, consideration of the true import of a by-law is facilitated. In Gray v. Medical Society of the Contnty of Erie, ${ }^{52} \mathrm{de}-$ cided in New York before the Ewald case subjected medical society discipline cases to the law of voluntary associations, the medical society's fee schedule was held to be the result of "a combination ... unlawful at common law"53 and against public policy as a restraint on trade. Therefore, a physician who had contracted to care for inmates of a public institution without regard to the schedule was ordered reinstated.

The law of voluntary associations, however, proved too much to overcome in the cases involving medical society discipline of doctors because of their membership in prepayment medical-care plans. Irwin v. Lorio, ${ }^{54}$ decided in 1930, was the first American case. The "reasonable competition" ethic ${ }^{55}$ had been used as the basis for resolutions passed by the East Baton Rouge Parish Medical Society aimed at destroying an industrial prepayment health plan. Three physicians under contract with the plan were charged with having violated the ethic by retaining their contracts. The expelled physicians and the prepayment plan filed separate suits to enjoin the society from voting on the expulsion charges; ${ }^{56}$ relief was denied to the former because of prematurity and lack of jurisdiction, and to the latter on the ground of no cause of action. ${ }^{57}$ The court said that the

[for] members of the board of supervisors [of the county hospital] contrary to the dignity and honor of the medical profession." Ibid.

51 "Any matter of policy involved in the adoption of the by-laws, the code of ethics, and the resolution in conformity therewith, is a question for the membership itself and is not debatable here so long as it is not shown that such policy is in violation of law." Tbid., at 270-71, 878. Aside from the question of the applicable law, the fact that a contempt order against the Board of Supervisors of the hospital under the 1933 decree was not sought indicates that more than just the standard of medical care was at stake.

5224 Barb. (N.Y.) 570 (1857).

${ }^{53}$ Ibid., at 576.

54169 La. 1090, 126 So. 669 (1930).

${ }^{65}$ Ibid., at $1093,669-70$; quoted at note 48 supra.

${ }^{56}$ The physicians alleged a conspiracy to destroy a property right (their contracts with the medical plan), and charged that denial of hospital facilities would be one of the consequences of expulsion. The medical plan alleged that expulsion would destroy the value of their contracts with the physicians. Ibid., at 1095-96, 670-71.

${ }^{57}$ The physician's suit was disposed of on the law of voluntary associations. See text at note 58 infra. As to the plan's suit, the court reasoned that the health plan had contracted with the physicians with reference to their right to join a medical society, and that it could not interfere with the trial of the physicians by the society. Tbid., at 1101-2, 672, relying on Green v. Board of Trade of Chicago, 174 Ill. 585, 51 N.E. 599 (1898). There it was held that the exist- 
society had power to expel for "legal cause" and to determine what constituted legal cause. "If [the expelled physicians] consider they did not have a fair and impartial trial . . . they may apply to the courts for relief. . . ."58

Sixteen years earlier, an English court had rendered a contrary decision in Pratt v. British Medical Association..$^{59}$ Members of a local division of the British Medical Association (BMA) ${ }^{60}$ had served on the staff of a lay-sponsored group prepayment plan until a controversy with the lay management led to their resignations and a subsequent resolution by the division providing that no member associate with the disapproved plan. Three physicians disregarded the resolution and joined the plan's staff; one of them was expelled and a boycott against all three was instituted by the society.

The physicians sued for damages and an injunction. The defendants admitted the acts alleged in the complaint but pleaded two grounds of justification-competition and ethics. ${ }^{61}$ Both damages and an injunction were granted on a finding of intentional interference with the plaintiff's calling through the use of threats and the enforcement of by-laws which were held to be in restraint of trade and void. ${ }^{62}$ The justification of competition was held untenable; "mere self-interest"

ence of a member's unperformed contracts will not prevent his trial and expulsion, since customers dealing with a member of an organization such as a board of trade are conclusively presumed to have dealt with reference to its rules. The Green case, however, is distinguishable on its facts. The rules there violated were express rules of the exchange against dealing in commodities without bona fide purchase orders; violation per se carried the taint of illegality. Further, "the particular vocation involved owe[d] its existence to the association concerned," and thus intervention could be said to be less justified than in the case of a profession, which "owes its existence to the needs of another and wider association, the community." Ford, op. cit. supra note 16, at 203 (drawing a distinction between religious bodies and trade unions). See Stock Exchange v. Board of Trade, 127 Ill. 153, 14 N.E. 855 (1889); and consult Carpenter, Interference with Contract Relations, 41 Harv. L. Rev. 728, 754 et seq. (1928).

${ }^{68}$ Irvin v. Lorio, 169 La. 1090, 1097, 1101, 126 So. 669, 671-72 (1930).

59 [1919] 1 K.B. 244.

${ }^{60}$ The organization of the BMA is similar to that of the AMA; it consists of a national organization and local component divisions. Cf. Group Health Cooperative of Puget Sound v. King County Medical Society, 39 Wash. 2d 586, 646, 237 P. 2d 737, 769 (1951); Pratt v. British Medical Association, [1919] 1 K.B. 244; Thompson v. New South Wales Branch, [1924] A.C. 764.

${ }^{61}$ I.e., they asserted that they had exercised coercion with the legitimate object of advancing their professional interests, and should thus be free from liability.

62 "Upon considering the rules in question $I$ have arrived at the conclusion that they are in restraint of trade, and are void on the ground of public policy. They gravely, and in my view unnecessarily, interfere with the freedom of medical men in the pursuit of their calling, and they are I think, injurious to the interests of the community at large. It may well be that the opinion I have just expressed will, if upheld, destroy the cogency of the defendant's scheme of boycott; but it leaves them with the safer and more kindly weapons of legitimate persuasion and reasoned argument." Pratt v. British Medical Association, [1919] 1 K.B. 244, 274-75. The scheme of boycott was effectuated through "model rules" promulgated by the BMA which the various divisions were free to adopt. One of the rules provided that no member should consult with a physician whose conduct had been declared by any division to have been "detrimental to the honour and interests of the [medicall profession." In addition, there was provision for notices to other divisions to render the boycott effective. Tbid., at $247-49$. 
or protection of trade interests was considered insufficient as a defense where coercive tactics were employed. ${ }^{63}$ The ethical justification (conduct detrimental to the interests of the medical profession) was ruled out because "the alleged $\sin$ [of the plaintiffs] was financial rather than moral in its character." ${ }^{\prime 64}$ In addition, there was a broad dictum to the effect that much of what the BMA had attempted was beyond the powers of a voluntary association. ${ }^{65}$

The Pratt case was not mentioned in either Irwin v. Lorio ${ }^{66}$ or Porler v. King County Medical Society. ${ }^{67}$ The Porter case involved an action for damages for inducing a breach of a contract between two doctors whose clinic handled group medical contracts, and the plaintiff, their business manager. The society's newly established subsidiary was competing for group contracts, and a resolution prohibiting any member from engaging in contract practice not authorized by the society had been promulgated. Pursuant to this resolution, the plaintiff's employers abandoned their contract with him and gave up their clinic.

A decision was rendered for the defendants because (1) an employee has no cause of action against a competitor of his employer, and (2)

It cannot be successfully contended that the medical society did not have the right to adopt the by-law in question. Whether such by-law or rule was just, reasonable, or wise is a question which concerns only the medical society and its members. The medical society, in the enforcement of its by-laws for the direct purpose of benefit to itself and its members is not answerable for damage incidentally resulting to a third person. ${ }^{68}$

But when the restrictive activities of the King County Medical Society were again before the Washington Supreme Court in Group Health Cooperative of Puget Sound v. King County Medical Society, ${ }^{69}$ this time on an action brought

${ }^{63}$ Ibid., at 266.

${ }^{64}$ Ibid., at 272.

${ }^{65}$ The dictum is posited on two principles that have broad application-lack of statutory authority and unreasonableness. "The coercive force of the defendant Association rests primarily upon what are called the ethical rules.... [T]he defendants claim to enforce by boycott and by the infliction of ruin, their own standards of medical honour and interest throughout the country. This point is momentous; it touches the vital interests of every medical man. He may be exposed to degradation and dishonour at the will of a body which is void of the slightest statutory sanction in that behalf." Ibid., at 269 . The court pointed out that the Medical Act of 1858, 21 \& 22 Vict., c. 90 (1858), created a General Medical Council with the power to maintain the character of the medical profession. "But the British Medical Association has taken to itself a jurisdiction more far-reaching, and perhaps more potent than that of the General Medical Council. It entrusts to a large extent the standard of 'honour and interests' of the medical profession to a number of scattered bodies throughout the country, which vary in numbers, inclination, views and self-interest. A branch or division may make a rule to suit its own local pecuniary interest. If that rule be broken, by a member of the defendant association or not, then he becomes subject to a declaration that he has acted against the honour and interests of the medical profession." Ibid., at 269-71.

${ }^{86} 169$ La. 1090, 126 So. 669 (1930), discussed in text at notes 54-58 supra.

${ }^{87} 186$ Wash. 410, 58 P. 2 d 367 (1936).

68 Ibid., at $419,370$.

6939 Wash. 2d 586, 237 P. 2d 737 (1951). 
under an anti-monopoly provision of the state constitution, ${ }^{70}$ the Porter case was distinguished $\mathrm{d}^{71}$ and the Pratt case was cited in support of a decision for the plaintiffs. ${ }^{72}$ The society attempted to justify its actions by contending that (1) medical services under contract practice in general and the Cooperative's services in particular were below AMA standards; ${ }^{73}$ (2) the plan denied free choice of a physician to its subscribers $;^{74}$ and (3) the Cooperative solicited patients. ${ }^{75}$

The court held the substandard charge unproved. ${ }^{76} \mathrm{It}$ concluded that the principle behind the society's interpretation was not "free choice of physician"

${ }^{70}$ Wash. Const. Art. XII, $\S 22$. The Cooperative's services were held to be a "product" under this constitutional provision. Group Health Cooperative of Puget Sound v. King County Medical Society, 39 Wash. 2d 586, 634-45, 237 P. 2d 737, 763-69 (1951).

71 "[T] there enforcing its by-laws, was pursuing its legitimate objects. . . The question of restraint of competition was not specifically put in issue in the pleadings, nor was it urged . . . on appeal. ... In the instant case, however, ... we cannot say ... that respondents are only in pursuit of their 'legitimate' interests." Ibid., at 660, 776.

72 Ibid., at 645,769 . The court's disposition of the defense's contention that the Pratt case was no longer good authority in England draws two important distinctions: (1) Ware \& De Freville, Ltd. v. Motor Trade Ass'n, [1921] 3 K.B. 40 [see United States v. American Medical Ass'n, 110 F. 2d 703, 711 (App. D.C., 1940)], and Sorrell v. Smith, [1925] A.C. 700, were said to be tried on the theory "that there had been a combination of persons wilfully to injure the defendants in their trade, with resulting damage. The court held, in each case, that the real purpose of the combination was not to injure another, but to forward their own trade interests, and that the acts were therefore not actionable. In neither of these cases was the specific question of combinations in general restraint of competition raised or discussed." Group Health Cooperative of Puget Sound v. King County Medical Society, supra, at 649, 770. (2) The bylaws involved in Thompson v. New South Wales Branch, [1924] A.C. 764, were said to be voluntary agreements to limit one's own trade or calling and not "as in the case before us, directed toward the restriction of the activities of third persons." Ibid., at 650,771 . The Thompson case concerned a doctor expelled because he had publicly maligned the character of fellow members of his local division. The plaintiff had argued that the by-law pursuant to which he had been expelled was in restraint of trade and void, but the House of Lords (without mention of the Pratt case) reasoned that the members of the BMA had bound themselves so as to limit their own trade or calling, and thus the BMA was free to act even if it constituted a restraint on one of them. But see Lee v. Showman's Guild of Great Britain, [1952] Q.B. 329, 343 , where it is said: "[D]omestic tribunals which sit in judgment on members of a trade or profession ... wield powers as great as, if not greater than, any exercised by the Courts of law. ... They can ban him from ... the only trade he knows. They are usually empowered to do this for any breach of the rules ... which they impose and which he has no real opportunity of accepting or rejecting. ... If he is to engage in the trade, he has to submit to the rules. ... Is such a tribunal to be treated by these courts on the same footing as a social club? I say no." Consult Ford, op. cit. supra note 17, at 203 et seq., for an evaluation of this quotation in the context of English law.

${ }^{73}$ Group Health Cooperative of Puget Sound v. King County Medical Society, 39 Wash. 2d 586, 605-11, 237 P. 2d 737, 748-51 (1951).

${ }^{74}$ Ibid., at 609-11, 750-51.

75 Ibid., at 613,752 . The society also charged that the Cooperative was collecting fees for services rendered by the physicians but not covered by the plan. This charge was held $d e$ minimis because substantially all of the physician's services were rendered under contract for a salary. Ibid., at 612,752 .

${ }^{76}$ Ibid., at 607-8, 749. 
but "equal access to patients." This was deemed an unreasonable interpretation of the ethic. ${ }^{77}$ In the absence of a showing of improprieties, the "solicitation" charge could not stand as long as the society-approved plan engaged in solicitation. ${ }^{78}$ The result was a finding that the term "unethical" had been grossly misused.

The medical society was also found guilty of overt acts of coercion, ${ }^{79}$ motivated by the desire to restrain competition in the industrial contract field in favor of its own open-panel service plan. ${ }^{80}$ The competition for industrial medical contracts, however, should not be taken as the sine qua non of the opinion, since the benefits from the demise of the Cooperative would have gone to the individual members of the medical society. The existence of their own prepayment plan would only have changed the form of remuneration from their increased clientele. ${ }^{81}$

The existence of a competing plan sponsored by a medical society does pro-

7 Ibid., at 611,751 . The court pointed out that the society's antagonism to all "unauthorized" contract medicine plans was predicated primarily on the premise that they preclude "free choice of physician," and concluded that this objection was unjustified. Ibid., at 609-11, 750-51.

${ }^{78}$ Ibid., at 614, 752-53. Cf. Complete Service Bureau v. San Diego County Medical Society, - Cal. 2d -, 272 P. 2d 479, 506 (1954).

${ }^{79}$ Among the specific acts detailed were:

(1) Threats to expel any doctor who furnished prepaid medical care in competition with the society plan.

(2) Exclusion of Cooperative physicians from Seattle hospitals even to the extent of denying them use of surgical and emergency facilities. The hospital exclusion policy was not effectuated by means of "formal agreements" but "through persuasion and economic pressure," which made it "very difficult for the Cooperative and its staff members to carry on their contract practice." Group Health Cooperative v. King County Medical Society, 39 Wash. 2d 586, 621-22, 237 P. 2d 737, 756-57 (1951).

(3) Refusal by the medical society to admit Cooperative physicians, regardless of qualifications or character, or to accept transfers of membership of doctors intending to render services to the group plan. Judicial notice was taken of the fact that membership in the local society was necessary for membership at state and national levels, "where advantage may be taken of broad programs of scientific and medical advance. . . . Perhaps more important than all these other considerations, a non-member of the Society is quite generally regarded as an outcast by his fellow practitioners, his patients, and members of the public, and suffers very real humiliation and embarrassment." Ibid., at 626, 759 .

(4) Although the rule against consultation with Cooperative physicians was not strictly enforced by the society and compliance was left to the judgment of individual members, assistance on a "regular" basis was thought to be unethical. The effect of "the policy ... respecting consultation has seriously handicapped the Cooperative in the rendition of competent medical service." Ibid., at $628,760$.

(5) Cooperative physicians were unable to obtain certification from specialty boards as a consequence of the membership exclusion policy. "[M]ost of those specialty boards require, as one prerequisite to certification, membership in the local medical society." Ibid., at 632, 762.

${ }^{80}$ Ibid., at $614,753$.

81 Thus, the court found "reason to believe that the purpose of the Society in restraining competition extends to the ultimate extermination of all contract practice by the Cooperative" in favor of "the regular fee-for-service practice of all [the] members of the society." Ibid., at $615,753$. 
vide a convenient measuring rod for determining whether the charges of unethical practices made against non-society plans and their affiliated physicians are valid. Such a comparison was made in Complete Service Bureau v. San Diego County Medical Society, ${ }^{82}$ where a prepayment group medical plan and three affliated physicians sought damages and equitable relief against the medical society in an action brought under the antitrust provision of California's Cartwright Act. ${ }^{83}$

The defendants filed a cross-complaint, in which it was alleged that Complete Service Bureau (1) solicited patients, (2) split fees with its lay manager, (3) used misleading advertisements, (4) was illegally engaged in the corporate practice of medicine, and (5) that these practices constituted unfair competition with respect to members of the San Diego.County Medical Society. ${ }^{84}$

The complainants dismissed the equity features of their complaint with prejudice, and the trial, involving only the issues of the cross-complaint, resulted in findings adverse to the medical society on all points and a denial of relief. ${ }^{85}$ At the end of the trial the society asked for a judgment on the pleadings;

82 - Cal. 2d -, 272 P. 2 d 497 (1954). The Complete Service Bureau is a nonprofit prepayment group-practice plan, but does not offer comprehensive care. The premiums entitle members to limited hospitalization and medical services from physicians under contract at a reduced fee.

${ }^{83}$ Cal. Bus. \& Prof. Code (Deering, 1951) $\$ 16720$ ("a combination ... (a) to create or carry out restrictions in trade or commerce"). The trial court held the amended complaint sufficient; "[it] sets forth the concerted action of the [defendants] to enforce interlocking rules and regulations which enable the medical societies to control the practice of medicine...." Complete Service Bureau v. San Diego County Medical Society, No. 149318 (1952) (memorandum opinion of Mundo, J., Super. Ct. of San Diego County, Cal.), at 7.

${ }^{84}$ Complete Service Bureau v. San Diego County Medical Society, - Cal. 2d -, 272 P. $2 \mathrm{~d} 497,499$ (1954). The principle contention under allegation (4) was that nonprofit medical service plans could not exist under Cal. Corp. Code (Deering, 1953) $\$ 9200$, which is the general nonprofit corporation provision in California. It was insisted that all such plans had to comply with $\$ 9201$, which provides that one-fourth of all licentiates of the particular profession involved become members of the corporation, and that an opportunity to render services for the corporation must be available to all of the licensed members of the profession. The court rejected this contention partly because "[i]f section 9201 should be held to be the only section under which a nonprofit medical service corporation may incorporate [the society-sponsored plan, California Physicians Service] might exercise a [legal] monopoly in that field. ..." Complete Service Bureau v. San Diego County Medical Society, supra, at 502 . Consult Hansen, Laws Affecting Group Health Plans, 35 Iowa L. Rev. 209, 222-29 (1950), for a discussion of similar restrictive statutes and their effect; see note 140 infra.

85 "The [trial court] found as a fact that: '[The County Medical Society], through their sponsorship of and participation in [their own plan] . . . engage in substantially the same policies and practices which they enumerate as unethical and unlawful acts on the part of [CSB] in connection with advertising . . ., soliciting of patients . . , paying unlicensed persons ... out of monies collected from patients, and using the name [of their own plan] for advertising purposes in connection with named physicians. ... None of the policies or activities of [CSB] is harmful. ... None of them tends to demoralize the medical profession. ... [or to] prevent the establishment and maintenance of adequate or reasonable standards. ... [or to] lower the standards of the medical profession or degrade the practice of medicine, to the detriment of health of anyone." " Complete Service Bureau v. San Diego County Medical Society, - Cal. 2d -, 272 P. 2d 497, 506 (1954). 
it was held that the original complaint as amended stated a good cause of action. ${ }^{86}$ This point was not appealed, ${ }^{87}$ but the California Supreme Court affirmed the decision on the cross-complaint. In addition, the court approved the trial court's method of evaluating the society's charges by comparing the practices of the medical-society-sponsored plan with the practices of the group medical plan.

The efficacy of the federal antitrust laws as a vehicle for relief from the tactics of organized medicine, even without the pretense of a competing medical society plan, was affirmed by the United States Supreme Court in American Medical Association v. United States. ${ }^{88}$ Group Health Association (GHA) was organized in 1937 as a lay-sponsored, nomprofit prepayment plan to serve federal employees in the District of Columbia. Difficulties with organized medicine were immediately apparent; ${ }^{89}$ as a precautionary measure GHA obtained a declaratory judgment ${ }^{90}$ that it was not engaged in the corporate practice of medicine ${ }^{91}$ or in the insurance business. ${ }^{92}$

${ }^{86}$ Disregarding the allegations pertaining to injunctive relief, the amended complaint in substance alleged ".. . that said San Diego County Medical Society, said California Medical Association, and said American Medical Association, now constitute ... a medical trust, each acting in harmony with the other and all conniving to promulgate and enforce interlocking rules and regulations which enable such medical trust to control the practice of medicine and influence the operation of hospitals in the County of San Diego ... and elsewhere...." There follows a long list of specific acts alleged to have been perpetrated against physicians affiliated with CSB, including expulsion, denial of membership, loss of consultation privileges with society members, denial of hospital facilities, etc. Complete Service Bureau v. San Diego County Medical Society, No. 149318 (1952) (Memorandum opinion of Mundo, J., Super. Ct. of San Diego County, Cal.) at 3-4.

${ }^{87}$ But cf. Associated Press v. United States, 326 U.S. 1 (1945), where "[t]he heart of the government's charge was that appellants had by concerted action set up a system of By-Laws which prohibited all AP members from selling news to non-members, and which granted each member powers to block its non-member competitors from membership." All AP members had assented to the By-Laws, but the Court held that "arrangements or combinations designed to stifle competition cannot be immunized by adopting a membership device accomplishing that purpose." Ibid., at 4, 19.

${ }^{88} 317$ U.S. 519 (1943), aff'g 130 F. 2 d 233 (App. D.C., 1942).

89 "[W]hile the [AMA convention, Atlantic City, 1937] was still in session the House of Delegates got wind of the organization of Group Health Association and promptly went into executive session.... So determined was the pressure of the medical hierarchy ... that Senator McCarran at first threatened a Congressional investigation...." James Rorty, "Organized Medicine" Sees Red, 145 Nation 500 (1937).

${ }^{90}$ Group Health Ass'n v. Moor, 24 F. Supp. 445 (D. D.C., 1938), aff'd sub nom. Jordan v. Group Health Ass'n, 107 F. 2d 239 (App. D.C., 1939).

${ }^{91}$ The rule that corporate practice of medicine is illegal was a result of early dentistry cases. The usual rationale is that corporations, being impersonal entities, are not qualified to practice the healing arts under licensure statutes requiring personal qualifications. For a discussion of the cases consult Hansen, op. cit. supra note 84, at 211-19; Levy \& Mermin, Cooperative Medicine and the Law, 1 Nat. Lawyers Guild Q. 194, 201-6 (1938).

92 The statutes regulating insurance companies and insurance contracts are too strict for the prepayment health plans, especially insofar as financial controls are concerned. Consult Hansen, op. cit. supra note 84, at 219-22; Levy \& Mermin, op. cit. supra note 91, at 209-11. 
Then organized medicine resorted to its available coercive measures. ${ }^{93}$ The Department of Justice obtained an indictment $t^{94}$ against the AMA and the district society alleging violations of Section 3 of the Sherman Act; ${ }^{95}$ its sufficiency was sustained on appeal after the district court had held that it did not show restraint of trade. The court of appeals, reasoning from the common law, held that the practice of medicine constituted a trade and that GHA was engaged in business, so that a restraint upon either could be a restraint of trade within the statute. ${ }^{96}$

The court also commented on the question of justification, saying that "it cannot be admitted that the medical profession may through its great medical societies, either by rule[s] or disciplinary proceedings, legally effectuate restraints as far reaching as those now charged." But the defense was not ruled out completely; "if there is any justification for the restraint, so as to make it reasonable as a regulation of professional practice, it must be shown in evidence as a defense. ..." "97

The trial resulted in the conviction of the AMA and the district society. On appeal, the court of appeals reiterated its previous holding that the practice of medicine was a trade, but chose to place primary reliance on the alternative holding that GHA was engaged in a trade or business. Thus, the existence of the separate entity of GHA provided a basis for applying the Sherman Act. ${ }^{98}$ The appeal was based primarily on the contentions that the Sherman Act was inapplicable because the controversy involved was a labor dispute and hence excluded from the scope of the Sherman Act by the Clayton and Norris-LaGuardia Acts, ${ }^{99}$ and "that their conduct was no more than a reasonable regulation of the practice of medicine." ${ }^{\prime 100}$ Three elements were held to negate the first contention: first, that the physicians involved were independent contractors; second, that the dispute was not one arising out of the employer-employee relationship; and

93 "The District Medical Society expelled or otherwise disciplined several of the doctors hired by Group Health; in some instances mere threats of such action led to resignation from the GHA staff. Moreover, the Society circulated a 'white list' of approved organizations and individuals, from which GHA was excluded, thereby making it impossible for GHA doctors to obtain consultation with fellow physicians. Furthermore Group Health had no hospital of its own but depended upon the availability and cooperation of local institutions ... [but] nearly all the hospitals ... [were enlisted] to deny GHA physicians staff privileges and bed space for their patients." Yale L. J., op. cit. supra note 1, at 990-91.

94 The indictment is summarized in American Medical Ass'n v. United States, 317 U.S. 519, 526-27 (1943).

9526 Stat. 209 (1890), 15 U.S.C.A. § 3 (1951).

${ }^{96}$ United States v. American Medical Ass'n, 110 F. 2d 703 (App. D.C., 1940), cert. denied 310 U.S. 644 (1940), rev'g 28 F. Supp. 752 (D. D.C., 1939), cert. denied 308 U.S. 599 (1939).

${ }^{97} 110$ F. 2d 703, 712 (App. D.C., 1940).

${ }^{98}$ American Medical Ass'n v. United States, 130 F. 2d 233 (App. D.C., 1942), aff'd 317 U.S. 519 (1943).

${ }^{99}$ Clayton Act, 38 Stat. 730 (1914), 15 U.S.C.A. $\$ \$ 12-27$, 44, 29 U.S.C.A. $\$ 52$ (1947); Norris-LaGuardia Act, 47 Stat. 70 (1932), 29 U.S.C.A. $\$ \$ 101-10,113-15$ (1951).

${ }^{100}$ American Medical Ass'n v. United States, 130 F. 2d 233, 244 (App. D.C., 1942). 
third, that "a physician is not a workman or a laborer . . . and his compensation is not wages. ..." "101

The appellants' second contention, "that a conspiracy 'entered into with the object of fairly regulating the practice of medicine ...' was not a violation of the Sherman Act," was held clearly erroneous: ${ }^{102}$ "Under no circumstances could the commission of crime be justified as a reasonable regulation of professional practice." 103 The court pointed out that the appellants were relying on arguments and cases "which seem to assume for them powers of a state legislature to enact and enforce laws to require improvement of standards of professional practice. ... Needless to say, appellants have no such power."104

The Supreme Court granted certiorari limited to three questions: (1) whether the practice of medicine or the medical services rendered by GHA were trade under the Sherman Act; (2) whether restraints of trade under the Sherman Act were charged and proved; and (3) whether there was immunity from prosecution under the Clayton and Norris-LaGuardia Acts. The Court did not rule on whether the practice of medicine was a trade. ${ }^{105}$ Instead, it held that GHA was

101 Ibid., at 242. The court indicated two situations in which the Clayton and NorrisLaGuardia Acts might be successfully pleaded by organized physicians as immunity from the Sherman Act: (1) when physicians employed on a contract basis formed associations for collective bargaining and (2) where the laity was organized so that it could set the prices or conditions of medical employment. Ibid., at 243. But see Apex Hosiery Co. v. Leader, 310 U.S. $469,487-89$ (1940).

102130 F. 2d 233, 244 (App. D.C., 1942). The court quoted from Anderson v. United States, 171 U.S. 604, 615-16 (1897), for the proposition of law that the appellants were relying on. The court there distinguished between agreements whose main purpose was to transact business between the parties with only incidental effects on commerce, and agreements designed to restrain

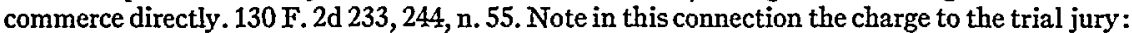
"If it be true ... that the District Society, acting only to protect its organization, regulate fair dealing among its members, and maintain and advance the standards of medical practice, adopted reasonable rules and measures to those ends, not calculated to restrain Group Health, there would be no guilt, though an indirect effect may have been to cause some restraint against Group Health." Quoted by the Supreme Court in American Medical Ass'n v. United States, 317 U.S. 519, 533 (1943).

${ }^{103}$ American Medical Ass'n v. United States, 130 F. 2d 233, 244 (App. D.C., 1942). AIthough the professions enjoy "licensed monopolies" which constitute "severe restraints upon competition," this was said to be no justification for "concerted criminal action to prevent the people from developing new methods of serving their needs.... The people give the privilege of professional monopoly, and the people may take it away." Ibid., at 246.

${ }^{104}$ Ibid., at 245. Concerning the legal status of the appellants and the powers that they could invoke, the court said that "in the absence of [legislative delegation of power] professional groups must abide by the general laws just as scrupulously as any private citizen or private corporation. It is in this setting that appellants were permitted to organize, to establish standards of professional conduct, to effect agreements for self-discipline and control." The distinction to be drawn was between "the use of such self-disciplines and effort upon the part of such associations to destroy competing professional or business groups or associations." Ibid., at 247-48. On the theme of abuse of powers, the court used language reminiscent of the New York Supreme Court in Ewald v. Medical Society of New York County, 70 Misc. 615, 130 N.Y. Supp. 1024 (S. Ct., 1911), rev'd 144 App. Div. 82, 128 N.Y. Supp. 886 (1911). American Medical Ass'n v. United States, 130 F. 2d 233, 249 (App. D.C., 1942).

${ }^{105}$ In United States v. National Ass'n of Real Estate Boards, 339 U.S. 485, 492 (1950), the Supreme Court again reserved the question whether the practice of a profession constitutes trade under the Sherman Act (real estate brokers). 
engaged in business or trade and that a "conspiracy to restrain and obstruct this business [is] a conspiracy in restraint of trade or commerce within the statute." ${ }^{106}$ As to the second point, the Court held that restraints under the Sherman Act were charged and that the jury could properly have found that they were calculated to restrain GHA. ${ }^{107}$ The third question was answered in the negative the dispute was not one concerning "terms and conditions of employment"108 - thus affirming the court of appeals and cementing the government's victory.

This victory was not repeated in United States v. Oregon State Medical Socie$t y,{ }^{109}$ where violations of Sections 1 and 2 of the Sherman Act ${ }^{110}$ were alleged. On direct appeal, ${ }^{\text {III }}$ the Supreme Court affirmed a federal district judge's dismissal of the indictment for failure of proof of a conspiracy to restrain private health plans. ${ }^{112}$ The opinion supports the district judge's discounting of all actions prior to 1941 alleged in the indictment, and recognizes that with this done, "little of substance is left. The case derived its coloration and support almost entirely from [practices abandoned in 1941]." "113 Since the post-1941 evidence did not prove a concerted refusal to deal with non-society health associations, the Court declined to decide whether such would violate the antitrust laws or whether interstate commerce was involved. ${ }^{114}$ The affirmance, however, was without prejudice to future suit in case the conduct of organized medicine in Oregon should at any time "threaten or constitute violations of the antitrust laws." "115

It is now settled that the restrictive actions of medical societies can violate the Sherman Act. The American Medical Association case reveals that the medical

${ }^{106}$ American Medical Ass'n v. United States, 317 U.S. 519, 528 (1943).

${ }^{107}$ Ibid., at 529 et seq.

${ }^{108}$ The Court held that $\S 20$ of the Clayton Act, 38 Stat. 738 (1914), 29 U.S.C.A. $\$ 52$ (1947), as expanded by $\S 13$ of the Norris-LaGuardia Act, 47 Stat. 73 (1932), 29 U.S.C.A. $\S 113$ (1947), was the only pertinent provision, and that "[t]he petitioners did not represent present or prospective employes. Their purpose was to prevent anyone from taking employment under Group Health." Ibid., at 536.

${ }^{109} 343$ U.S. 326 (1952), aff'g 95 F. Supp. 103 (D. Ore., 1950).

${ }^{110} 26$ Stat. 209 (1890), as amended, 15 U.S.C.A. $\$ \$ 1,2$ (1951).

iu Pursuant to $\S 2$ of the Expediting Act of 1903, 32 Stat. 823 (1903), as amended, 15 U.S.C.A. $\$ 29$ (1951).

112343 U.S. 326, 329-37 (1952), aff'g 95 F. Supp. 103 (D. Ore., 1950). The other charge in the indictment alleged conspiracy between society-sponsored plans to restrict competition, and was dismissed for want of interstate commerce. Ibid., at 338. The affirmance was not unanimous, Justice Black voting for reversal. Ibid., at 340 .

113 Ibid., at 334. But the Court observed in passing "that there are ethical considerations where the historic direct relationship between patient and physician is involved which are quite different than the usual considerations prevailing in ordinary commercial matters. This Court has recognized that forms of competition usual in the business world may be demoralizing to the ethical standards of a profession. Semler v. Oregon State Board of Dental Examiners, 294 U.S. 608." Tbid., at 336.

114 Ibid.

115 Ibid., at 339-40. 
service corporations themselves may be the basis for a finding of trade. A serious obstacle, however, to antitrust prosecution is the difficulty of proving a conspiracy. The two cases in which relief was granted were characterized by overt coercion; "indirect, less overt opposition probably discourages physicians from affliating with disapproved plans, but is less suceptible to anti-trust prosecution."'116 Another obstacle under federal antitrust laws, the requirement of interstate commerce, effectively precludes judicial relief in most cases, ${ }^{117}$ since "practically all ... plans operate within the confines of a single state."118 The absence of the interstate aspect in many situations thus makes the state antitrust statutes of prime importance.

State antitrust law is an unclear field, and the comparative newness of the medical-plan problem makes prediction even more uncertain. The rendition of personal services and service industries have been held not subject to some state antitrust laws on the ground that labor is not a commodity or commerce. Under this view, laundry services, the sale and purchase of real estate, and baseball have been held not subject to state antitrust laws.119 On the other hand, telephone services, ice manufacture and an auto livery business have been held to be within the purview of state acts. ${ }^{120}$ And in the Puget Sound case, medical services rendered in connection with pre-paid medical service contracts were held to constitute "products" within the meaning of the Washington constitutional provision against monopolies. Insurance has been held a commodity for the purpose of state antitrust prosecution, ${ }^{121}$ and trade-association sanctions against members have similarly been held to be restraints on trade by state courts. ${ }^{122}$

26 Yale L. J., op. cit. supra note 1, at 1020. "Only the Multnomah County Medical Society resorted to expulsion of doctors because of contract-practice activities, and there have been no expulsions for such cause since 1941. There were hints in the testimony that Multnomah was reviving the expulsion threat a short time before this action was commenced, but nothing came of it, and what that Society might do within the limits of its own membership does not necessarily indicate a joint venture or conspiracy with other appellees." United States v. Oregon State Medical Society, 343 U.S. 326, 334-35 (1952).

117 Cf. United States v. Oregon State Medical Society, 343 U.S. 326 (1952). American Medical Ass'n v. United States, 317 U.S. 519 (1943), was brought under $\S 3$ of the Sherman Act, relating to the District of Columbia, and a showing of interstate commerce was not necessary.

118 Yale L. J., op. cit. supra note 1, at 1020.

119 State v. McClellan, 155 La. 37 , 98 So. 748 (1923); State v. Green, 344 Mo. 985, 130 S.W. 2d 475 (1939); Downing v. Lewis, 56 Neb. 386, 76 N.W. 900 (1898); American League Baseball Club of N.Y.v. Pasquel, 187 Misc. 230, 63 N.Y.S. 2d 537 (S. Ct., 1946); Nasman v. Bank of New York, 49 N.Y.S. 2d 181 (S. Ct., 1944).

${ }^{120}$ Home Telephone Co. v. Granby \& Neosho Telephone Co., 147 Mo. App. 216, 126 S.W. 773 (1910); Dietrich v. Cape Brewery and Ice Co., 315 Mo. 507, 286 S.W. 38 (1926); Ohio v. Greater Cleveland Livery Owners Assn., CCH 1946-47 Trade Cases 157,614 (Ohio Com. Pleas, 1947).

121 Speegle v. Board of Fire Underwriters of the Pacific, 158 P. 2d 426 (Cal. App., 1945).

${ }_{122}$ Marsh-Burke Co. v. Yost, 98 Neb. 523, 153 N.W. 573 (1915); Ertz v. Produce Exchange, 82 Minn. 173, 84 N.W. 743 (1901); see People v. Masiello, 177 Misc. 608, 31 N.Y.S. 2d 512 (S. Ct., 1941). 
The Donnelly Act in New York extends its prohibitions to services, ${ }^{123}$ and the complaint in the Complete Service Bureau case was held by the trial court to state a good cause of action under California's Cartwright Act. ${ }^{124}$ Most of the other state statutes are phrased in terms of articles of trade, commerce, commodities, business or manufactures. ${ }^{125}$ Whether medical services rendered on an individual basis or through the intermediary of a medical service plan can be brought within these statutes is questionable. ${ }^{126}$

II

Medical society opposition to prepayment group medical practice is composed of economic, psychological and ethical elements. The economic element stems from the removal from the medical market of the subscribers to group plans, the psychological element from the physician's fears of socialized medicine and his competitive disadvantage to group plans, and the ethical element from long-existing standards of professional conduct. The psychological and economic components of medical hostility to group medical plans are transmuted into and find expression in ethical objections to the group plans. Thus, action against the physicians connected with these plans is almost always phrased in ethical terms, e.g., (1) substandard or inadequate medical care, (2) the professional disapprobation of solicitation, (3) the right of unrestricted free choice of physician.

The claim that prepayment group practice will deteriorate the quality of medical care seems to be predicated, in actuality, on fear of vitiation of the doctor-patient relationship. It is argued first, that remuneration on other than a fee-for-service basis shifts the physicians' basic loyalty away from the patient. ${ }^{127}$ This charge perhaps had some validity when applied to early profit medical service plans: ${ }^{128}$ but it is less applicable to the more recent nonprofit plans where the medical aspects are usually exclusively under the control of doctors. ${ }^{129}$ In fact, in the latest case involving a nonprofit plan, the adequacy

${ }^{123}$ N.Y. General Business Law (McKinney, 1954) $\$ 340$ : "Every contract, agreement, arrangement or combination whereby ... [c]ompetition or the free exercise of any activity in this state in the ... supply ... of any ... service ... is or may be restrained or prevented, or whereby for the purpose of ... unlawfully interfering with the free exercise of any activity within this state in the ... sale of any ... service, the free pursuit in this state of any lawful business, trade or occupation is or may be restricted or prevented, is hereby declared to be against public policy, illegal and void."

124 Cal. Business \& Professions Code (Deering, 1951) § 16720.

${ }_{12}$ E.g., Ark. Stats. (1947) vol. 6, tit. 70, c. 1; La. Const. Art. 19, §14; Neb. Rev. Stat. (1943) c. 59, Art. 1; Minn. Stats. (1954) c. 623.

${ }^{326} \mathrm{~A}$ possible method of bringing them within the commodity clauses of some of the statutes is to consider medical service plans as engaged in the sale of indemnity against the costs of illness.

${ }^{127}$ See, e.g., Master, op. cit. supra note 3, at 766-67.

${ }^{128}$ Consult Hansen, op. cit. supra note 84, at 218-19.

${ }_{129}$ Memorandum for Dr. Landess, op. cit. supra note 6, at 6; Yale L. J., op. cit. supra note 1 at 986, n. 394; see Cooperative Health Federation of America, Body of Policy (1949). 
of the medical services rendered to patients was not even questioned. ${ }^{130}$ The second argument, that rapport between doctor and patient is hindered or destroyed when a patient does not exercise "unrestricted free choice of physician" can only be pieced together through implication. In order to use this argument against group health plans, it must be assumed that a doctor-patient relationship is imbued with positive healing qualities, and that such a relationship is impossible in group medical practice. Both assumptions are subject to question. Advocates of group medical practice argue that the doctor-patient relationship is not vitiated by group practice, and the argument might be made that a more non-personal and objective relationship may improve rather than impair the quality of medical care. To date, organized medicine has failed to substantiate either that medical service plans vitiate the doctor-patient relationship or that the standards of medical care are adversely affected..$^{131}$

The professional disapproval of solicitation presents a more formidable obstacle to group medical plans, whose formation, if not survival, is dependent upon some method of making their features known to large groups of people. The origin of this principle can probably be traced to organized medicine's long fight against itinerant charlatans and quacks, an area in which regulation has now been assumed by the states. Therefore, the ethical premise of the prohibition against advertising, "[to protect] the public from the advertiser and salesman of medical care, ${ }^{\prime 132}$ no longer rests on the same firm ground..$^{133}$

Absent historical necessity, and disregarding the conservatism which may be responsible for the preservation of the ethic against advertising, the thrust of the ethic is reduced to a limitation on methods of competition. Ideally, it dictates that competition be based on ability alone; unfortunately, it has served as a vehicle for medical hostility to novel methods of medical care which offer unwanted competition to solo, fee-for-service practitioners. In view of these considerations, the AMA's Judicial Council's reversal of the Landess case appears sound, and frees medical service plans from concern about this aspect of opposition.

The issues involved were far from unimportant, although disapproval of advertising by medical service plans was always open to question because of the intensive solicitation and advertising that the Blue Shield indemnity plans,

${ }^{130}$ Complete Service Bureau v. San Diego County Medical Society, - Cal. 2d -, 272 P. 2d 497, 501 (1954).

${ }^{131}$ See Complete Service Bureau v. San Diego County Medical Society, ibid.; Group Health Cooperative of Puget Sound v. King County Medical Society, 39 Wash. 2d 586, 237 P. 2d 737 (1951); consult notes 79, 85 supra.

132 AMIA, Principles of Medical Ethics, c. I, $\$ 4$.

133 "It is even being suggested, and the courts have expressed the opinion, that it should be proper and ethical for a physician to insert an advertisement in a newspaper or magazine depicting in a fair and truthful manner the character or quality of service which a member of the profession offers to the public." Complete Service Bureau v. San Diego County Medical Society, No. 149318 (1952) (memorandum opinion of Mundo, J., Super. Ct., San Diego County, Cal.), at 35 . 
sponsored by organized medicine, are permitted. ${ }^{134}$ Differentiation in treatment was justified on the rationale that all physicians in the community are eligible to participate in and benefit from the society plans, the patient remaining free to choose a physician from the general medical market. But advertising by medical plans is necessary to assure coverage of a sufficiently large number of persons to permit sound actuarial principles to obtain. This has been recognized by organized medicine as sound, ${ }^{135}$ and the judicial council's disposition of the Landess case suggests that henceforth the national association will not approve of disciplinary action against physicians affliated with medical service plans imposed merely because the plans engage in advertising.

The Landess decision, however, does not dispose of all the issues with finality. It expressly dictates that "the record ... is inadequate to determine the many ethical problems arising out of HIP's relationship to its subscribers and physicians. ..." 136 These problems arise from the requirement that "the ethical principles actuating and governing a group or clinic [be] exactly the same as those applicable to the individual."137 Under this mandate, the standards promulgated by organized medicine have been available as weapons against disapproved economic changes in medicine. ${ }^{138}$ The use of the "unrestricted free choice" rule,

${ }^{134}$ It is contended that the advertising practices of United Medical Service (the society plan in New York) are not different from those of HIP. "Insofar as UMS is a service plan it could be claimed that its advertising redounds to the benefit of UMS contracting physicians just as it is claimed that HICP advertising redounds to the benefit [of physicians affliated with HIIP]." Memorandum for Dr. Landess, op. cit. supra note 7, at 14. The Society's answer to this is that "the issue as to whether the practices of HIP are more or less ethical than any other prepaid medical plan is definitely not before this Tribunal and its determination on this appeal should not be influenced by issues not before it." Memorandum in Behalf of the Medical Society of the County of Queens, before the House of Delegates, Medical Society of the State of New York, Matter of Ben E. Landess, M.D., at 23 (hereinafter cited as Memorandum for the Society). Consult note 85 supra.

135 In 1946 the Judicial Council of the AMI said that "solicitation of probable . . . insurees is necessary to the success of medical insurance plans and is permitted," quoted in Memorandum for Dr. Landess, op. cit. supra note 6 , at 11 , and similar indorsement was given by the AMA's Council on Medical Service in its Suggested Principles for Lay Sponsored Health Plans, 140 J. Am. Med. Ass'n 686 (1949). In 1949 the Queens County Medical Society (New York) also gave express approval to advertising by HIP; the present reversal of this policy is defended as a bona fide change in mind. Memorandum for the Society, op. cit. supra note 134, at 14-15: The suggested principles were attacked as being exceptions to the codes of medical ethics, designed to "ease the restrictions" and "permit the establishment of a new concept in medical practice" which "from the beginnings of the medical profession had been known to be unethical." Ibid., at 10. But in the Landess appeal the Judicial Council reasserted the applicability of the twenty principles; "[t]hese ... Principles, although not amendments to the Principles of Medical Ethics, are certainly to be given full consideration in interpreting and applying them." Appeal of Dr. Ben E. Landess, op. cit. supra note 8, at 754.

${ }_{136}$ Appeal of Dr. Ben E. Landess, op. cit. supra note 8, at 754.

${ }^{137}$ AMA, Principles of Medical Ethics, c. I, $\$ 3$.

${ }^{138}$ "The evidence leads me to the conclusion that the subject of ethics in advertising is gradually being tied into economical situations with the original pious concepts giving way to new rules or new constructions of old rules to meet current problems affecting the medical profession." Complete Service Bureau v. San Diego County Medical Society, No. 149318 (1952) (memorandum opinion of Mundo, J., Super. Ct., San Diego County, Cal.), at 34-35. 
whose primary ethical justification lies in a desire to maintain the psychologically subtle and allegedly important doctor-patient relationship, is the most important example of this. ${ }^{139}$

The real heart of the controversy lies in the AMA's "great stress upon placing control [of prepayment plans] in professional hands. Such control involves two aspects: over standards of medical care, and over terms of physician participation. ... The power to set terms of physician participation means determination of the methods of practice and the type and level of doctor remuneration." 140 Since control over the standards of care is readily granted to the professionals in most plans, ${ }^{141}$ the crucial factors would appear to be control over the "terms," which are economic and not ethical considerations. That the societies really seek this more inclusive control is evident from examination of the restrictive state legislation they have fostered. ${ }^{142}$ The practical effect of this

${ }^{139}$ Consult generally, Master, op. cit. supra note 3 . Empirical data tend to support the view that the formal freedom advocated in "free choice of physician" has no correlation to the effective freedom of such free choice for most urban families. Surveys indicate that a majority of the people in lower income brackets do not have a family physician, and that where they do it is seldom on a regular basis. Families with low incomes are reluctant to consult a doctor because of the costs, and medical care is often discontinued because of financial difficulties. Stern, American Medical Practice: The Commonwealth Fund (1945); Carlton, The Problem of Social Medicine: Equilibrating the Distribution and Technology of Medical Care, 236 New Eng. J. Med. 493 (1947); Swackhamer, Choice \& Change of Doctors: Committee on Research in Medical Economics (1939). Under prepayment group-practice plans this picture is reversed. In HII, for example, almost all of the insurees select a "family" doctor whom they retain, and who is able to use his group's laboratory, X-ray facilities, and the consulting services of specialists for the benefit of his patients without any extra costs. It is admitted that "free choice" in the formal sense within HIP is limited, but what choice there is can be exercised without financial deterrents. "From the subscribers' standpoint, the plan provides a wide element of 'free choice.' The subscribers exercise their choice originally when they elect to join. Thereafter they may at any time discontinue their monthly subscription and go to any physician outside the plan whom they prefer and can afford to pay. If they choose to remain in the plan, they may select any medical group serving their area and may choose one of the family physicians within that group as their personal physician. They may freely change to another family physician within the group, or if they prefer, they may transfer to another group." Memorandum for Dr. Landess, op. cit. supra note 6, at 5.

140 Yale L. J., op. cit. supra note 1, at 986.

${ }^{141}$ See Cooperative Health Federation of America, Body of Policy 9 (1949).

${ }^{142}$ Consult Hansen, op. cit. supra note 84, at 222-29. These state statutes render it impossible for any prepayment medical care plan to be formed under them unless sponsored by the organized profession, by requiring medical society approval or a high minimum doctor participation. Thus, some of the statutes make the selection of directors subject to approval or appointment by the state medical association, e.g., N.J. Rev. Stat. (Cum. Supp., 1940) $\$ 17.48 \mathrm{~A}-2$. In others, a majority of the directors must be licensed physicians, e.g., Fla. Stat. (1953) $\S 641.02(3)$. Some acts require that all licensed physicians in the area or in the state be permitted to participate in the plan, e.g., Pa. Stat. Ann. (Purdon, Cum. Supp., 1954) tit. 15, \$ 2851-1508; Me. Rev. Stat. (1954) c. 60, §246; Ohio Rev. Code (Baldwin, 1954) c. $1737.06(B-1)$. Some require at least fifty per cent of the licensed physicians to participate, e.g., S.C. Code of Laws (1952) $\$ 37-1106$. Others require a specified number of doctors to start the plan, e.g., Ia. Code (1954) $\$ 514.17$. But eight states have statutes which permit the organization of lay-sponsored prepayment group-practice plans, e.g., N.Y. Insurance Law (McKinney, 1954) § 250 et seq.; Wash. Rev. Code (1951) $\$ 48.44 .010$. And three states have adopted separate, parallel acts for such plans, e.g., Ill. Stat. Ann. (1954) c. 32, $\S 595$ et seq. 
"free choice" legislation is to give the societies a legal monopoly in the field of prepaid medicine in many states.

But even when cast in the ethical nomenclature of "free choice," the private practitioners' economic objections to prepayment group-practice plans have a sound basis in fact. Subscribers of a closed-panel plan are removed from the medical market; HIP, for example, has some 400,000 subscribers. Thus, a physician who loses a patient to HIP feels its economic thrust directly, and can do very little to remedy the situation because the economies of prepayment group practice place him in a disadvantageous competitive position. Further, solicitation on his own is barred both by medical ethics and by medical practice acts, lending credence to the objections of solo practitioners that they are faced "with a form of advertising as competition."143

Nevertheless, Society opposition to medical service plans is predicated solely on charges of unethical practices; it is contended that the economics of prepayment group practice are irrelevant. E.g., "what is most relevant and material . . . is that 1,694 physician members of the County Society . . . desire to uphold the dignity and honor of the profession ...," which is endangered when in exchange for the economic advantages of HIP membership "the public is asked to surrender its right of unrestricted free choice of physician."144

III

The power of a voluntary association over its membership has rarely been fettered. Still, the influence of some organizations on the community's economic life is undeniable. When axioms of economic freedom conflict with the traditional self-government of the voluntary association, the dispute becomes of interest to society as a whole.

The general problem of the doctor and the power exerted by organized medicine has been glossed over by the courts. But within this larger problem, the conflict between professional standard-setting and emerging concepts of medical economics has had sufficient effect on society occasionally to invoke judicial interference.

To date, the doctrine of restraint of trade has been invoked only when the

${ }^{143}$ Memorandum for the Society, op. cit. supra note 135, at 15-16. "[G]roup practice may siphon off some of the fees which would otherwise go to the individual practitioner, but... many ... hold that group practice will be beneficial to the profession as a whole. . . The increased interest in health and medical service would have the natural reaction of bringing many to the individual practitioner who otherwise might be prone to defer their visits to a doctor's office." Complete Service Bureau v. San Diego County Medical Society, No. 149318 (1952) (memorandum opinion of Mundo, J., Super. Ct., San Diego County, Cal.), at 38.

${ }^{144}$ Memorandum for the Society, op. cit. supra note 134, at 7, 18. "The appellant takes refuge in the fact that the free choice of physicians is limited to economic status and perhaps geographical location. These limitations, however, are natural and the usual limitations contemplated by the codes of medical ethics. But, where a plan of operation introduces new artificial limitations such as limiting a choice of physicians to a selected group, the command of the Codes of Ethics, that free choice of physicians be maintained, is disregarded." Ibid., at 19. 
most overt sort of action has been directed against doctors because of their affiliation with group-practice prepayment plans. Whether judicial protection will be applied against the more subtle methods of coercion, or to the individual practitioner, remains a matter for speculation.

For this purpose, the cases provide little guidance except insofar as they delineate more technical problems such as proof of conspiracy and permissible defenses. They indicate that organized medicine can justify the regulation of its members' practices through ostensible enforcement of the code of medical ethics, except where the economic interests of third parties are affected. There, justification must be shown, and enforcement must not be contrary to public policy or law (i.e., in restraint of trade). Whether attempts by organized medicine to curtail or destroy prepaid medical service plans will conform to public policy in this sense is at best arguable and at least doubtful.

\section{LAW APPLICABLE TO CLATMS OF UNITED STATES FOR CON- TRIBUTION OR INDEMNITY IN FTCA CASES}

The Federal Tort Claims Act ${ }^{1}$ provides that tort actions against the government shall be governed by the law of the place where the tort occurred. ${ }^{2}$ In accordance with this provision, the rights and liabilities of parties in proceedings under the Act have generally been determined according to local law. ${ }^{3}$

The FTCA contains no provision for contribution or indemnity, either in

160 Stat. 842 (1946), 61 Stat. 722 (1947), 28 U.S.C.A. $\$ \$ 1291,1346,1402,1504,2110$, $2401,2402,2411,2412,2671-80$ (1950).

228 U.S.C.A. $\$ 1346$ (Supp., 1954) confers on the federal district courts "exclusive jurisdiction of civil actions on claims against the United States, for money damages . . . for injury or loss of property, or personal injury or death caused by the negligent or wrongful act or omission of any employee of the Government while acting within the scope of his office or employment, under circumstances where the United States, if a private person, would be liable to the claimant in accordance with the law of the place where the act or omission occurred." 28 U.S.C.A. \$2674 (1948) provides that "The United States shall be liable, respecting the provisions of this title relating to tort claims, in the same manner and to the same extent as a private individual under like circumstances. ..."

${ }^{3}$ E.g., Rushford v. United States, 204 F. 2d 831, 832 (C.A. 2d, 1953); United States v. Gaidys, 194 F. 2d 762, 764 (C.A. 10th, 1952).

But local law has been found inapplicable to determine certain questions arising under the Act where uniform federal standards were deemed appropriate. Thus, federal rather than local standards are employed to determine when a tortfeasor is an employee of the United States within the scope of his employment. United States v. Sharpe, 189 F. 2d 239, 241 (C.A. 4th, 1951); Field v. United States, 107 F. Supp. 401, 405 (N.D. Ill., 1952); Williams v. United States, 105 F. Supp. 208, 209 (N.D. Cal., 1952); see Hubsch v. United States, 174 F. 2d 7 (C.A. 5th, 1949). Other courts, however, have decided this question without reference to federal standards, e.g., United States v. Stewart, 201 F. 2d 135 (C.A. 5th, 1953); Murphey v. United States, 179 F. 2 d 743 (C.A. 9th, 1950).

The class of permissive plaintiffs under the Act has also been found to constitute a question for federal rather than local determination. Feres v. United States, 340 U.S. 135 (1950), denied the right of a serviceman or survivor to institute a claim under the Act for serviceconnected injuries. Accord: Sigmon v. United States, 110 F. Supp. 906 (W.D. Va., 1953); 